\title{
Characterization of Corrosion Behavior of Irradiated X65 Low Carbon Steel in Aerobic and Unsaturated Gaomiaozi Bentonite
}

\author{
Canshuai Liu, ${ }^{1,2}$ Jianqiu Wang ${ }^{1} \cdot$ Zhiming Zhang $^{1} \cdot$ En-Hou Han ${ }^{1} \cdot$ Wei Liu ${ }^{3} \cdot$ \\ Dong Liang $^{3} \cdot$ Zhongtian Yang $^{3}$
}

Received: 22 March 2018/Revised: 25 April 2018/Published online: 30 May 2018

(C) The Chinese Society for Metals and Springer-Verlag GmbH Germany, part of Springer Nature 2018

\begin{abstract}
$2.98 \mathrm{kGy} / \mathrm{h}(1007 \mathrm{~h})$ gamma irradiation and $90{ }^{\circ} \mathrm{C}(2000 \mathrm{~h})$ thermal aging were exerted to X65 grade low carbon steel buried in Gaomiaozi bentonite containing $17 \mathrm{wt} \%$ Beishan groundwater. The average corrosion rate of X65 low carbon steel was measured. The elemental and phase distribution on cross section was characterized by using electron probe micro-analysis, high-resolution X-ray diffraction, and micro-X-ray diffraction. The following conclusions can be made: the average aerobic corrosion rate of the carbon steel is $(45.16 \pm 1.53) \mu \mathrm{m} / \mathrm{year}$. Taking the original surface as boundary, the corrosion scale is divided into an internal dense product layer (DPL) mainly composed of $\mathrm{Fe}_{3} \mathrm{O}_{4}$ with segregated $\mathrm{FeCO}_{3}$ at the corrosion front and an external DPL mainly composed of $\mathrm{Fe}_{3} \mathrm{O}_{4}$ with segregated $\alpha-\mathrm{Fe}_{2} \mathrm{O}_{3}$ and bentonite at some relics. $\mathrm{Si}, \mathrm{S}$, and $\mathrm{Cl}$ are concentrated at the corrosion front of the internal DPL, while $\mathrm{Si}$ and $\mathrm{Al}$ are concentrated at the external DPL.
\end{abstract}

Keywords Low carbon steel $\cdot$ Corrosion rate $\cdot$ Phase distribution $\cdot$ Elemental concentration

\section{Introduction}

China has been investigating the geological disposal of high level radioactive waste (HLW) since 1985 [1, 2], selecting the multi-barrier system concept as a mode of constructing HLW repository. In this mode, HLW vitrification is placed in metallic canister which is buried in granite or claystone host rock with bentonite backfilled and buffer materials (Fig. 1). Canister is the first engineered barrier to isolate the radioactive nuclide from biosphere, and the carbon steel [3] is one of the reliable materials to fabricate the canister because of its high predictability to

Available online at http://link.springer.com/journal/40195

Jianqiu Wang

wangjianqiu@imr.ac.cn

1 Key Laboratory of Nuclear Materials and Safety Assessment, Institute of Metal Research, Chinese Academy of Sciences, Shenyang 110016, China

2 University of Chinese Academy of Sciences, 19 Yuquan Road, Beijing 100049, China

3 China Institute for Radiation Protection, Taiyuan 030006, China general corrosion and low susceptibility to localized corrosion.

The corrosion behavior of the carbon steel canister is closely related to the repository environment, including the redox state [4, 5], moisture content [6], temperature [7], and irradiation [8]. Therefore, the investigation on carbon steel corrosion behavior should be conducted in simulating repository environment. As proposed in Sweden [9], Canada [10], French [11], Japan [12], and the UK [13], the repository environment evolves with time. During the initial one thousand years after the closure of repository, the corrosion environment around the carbon steel canister can be aerobic, bentonite-unsaturated, high-temperature, and high-dose irradiation [9-14]. Then, after one thousand years, the repository environment gradually becomes anaerobic, bentonite-saturated, low-temperature, and lowdose irradiation [9-14]. It can be indicated that the aerobic corrosion rate of the carbon steel during the initial aerobic period should be significantly higher than the anaerobic corrosion rate during the latter anaerobic period.

However, most of the simulating investigations on the carbon steel canister corrosion behavior have been focused on the latter anaerobic period. Martin et al. [15-17] and Schlegel et al. $[18,19]$ investigated the corrosion behavior 


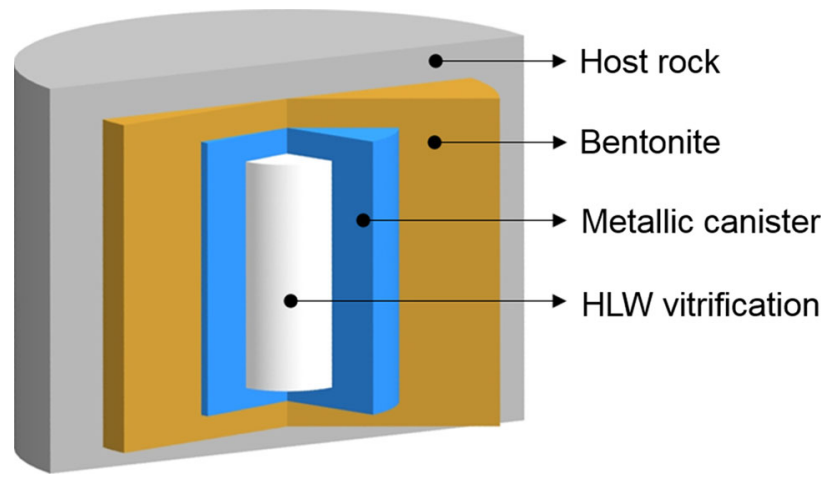

Fig. 1 The schematic showing of the multi-barrier system concept in China

of carbon steel in anaerobic and saturated MX-80 and Callovo-Oxfordian clay at $90{ }^{\circ} \mathrm{C}$ for up to 40 months. They found that the corrosion rate of carbon steel was more than $20 \mu \mathrm{m} /$ year at the beginning and decreased to $3 \mu \mathrm{m} / \mathrm{year}$ after the protective corrosion product layers being generated. The corrosion scales were composed of internal $\mathrm{Fe}_{3} \mathrm{O}_{4}$ and external Fe-rich phyllosilicate. Neff et al. $[20,21]$ analyzed the phase of corrosion products on anaerobic archeological iron at room temperature during several centuries, and they claimed that the corrosion film was composed of $\mathrm{Fe}_{3} \mathrm{O}_{4}, \alpha-\mathrm{Fe}_{2} \mathrm{O}_{3}, \alpha-\mathrm{FeOOH}$, and $\mathrm{FeCO}_{3}$. Smart et al. [22] investigated the effect of gamma irradiation on the corrosion behavior of carbon steel. They found that $300 \mathrm{~Gy} / \mathrm{h}$ gamma irradiation accelerated carbon steel corrosion rate by 30 times. In summary, the anaerobic corrosion process of the carbon steel canister has been investigated intensively.

The researches on the carbon steel corrosion behavior during the initial aerobic period of disposal have rarely been published. Ishiguro et al. [6] and Honda et al. [23] measured the corrosion rate of the carbon steel in aerobic bentonite slurry as $1-100 \mu \mathrm{m} /$ year, and detected the phase of the corrosion products as mainly $\mathrm{Fe}_{3} \mathrm{O}_{4}$, while further characterizations of the corrosion products, such as element and phase distribution, have not been conducted. Most researches concerning the effect of gamma irradiation have been conducted in aerobic solution, which is really different from the disposal environment.

In order to investigate the practical corrosion behavior of the carbon steel during the initial one thousand years of disposal, this study simulated the repository environment by aerobic and unsaturated bentonite with gamma irradiation and thermal aging. The corrosion rates were measured by weight loss measurement. The surface and cross-sectional morphologies of corrosion scale were characterized by using scanning electron microscopy (SEM). The chemical compositions of corrosion scale were detected by energy-dispersive X-ray spectroscopy (EDS). The element distribution on cross section was characterized by using electron probe micro-analysis (EPMA) and transmission electron microscopy with EDS (TEM-EDS). The phase type and distribution were determined by high-resolution $\mathrm{X}$-ray diffraction (HRXRD), and micro-X-ray diffraction ( $\mu$-XRD), respectively.

\section{Experimental}

\subsection{Materials and Samples}

X65 low carbon steel controlled by thermomechanical control process (TMCP) was used in this work, and its chemical composition is listed in Table 1. Samples with dimension of $10 \mathrm{~mm} \times 10 \mathrm{~mm} \times 1 \mathrm{~mm}$ for immersion tests were cut from a pipe (D $1500 \mathrm{~mm} \times 11.1 \mathrm{~mm}$ ) along axial direction. All samples were mechanically ground with silicon carbide paper up to 2000 grit, rinsed with ethanol, and dried in cold air immediately. Tables 2 and 3 list the chemical compositions of Gaomiaozi bentonite and Beishan groundwater which were used as medium in this work. The $\mathrm{pH}$ of Beishan groundwater is 7.56 , and the $\mathrm{pH}$ of Gaomiaozi bentonite is 8.53 .

\subsection{Irradiation and Thermal Aging Test}

At first, the original surfaces of the polished samples were partially marked by nanoscale $\mathrm{Au}$ particles. Then the samples were buried in Gaomiaozi bentonite containing $17 \mathrm{wt} \%$ Beishan groundwater and sealed in a 304 stainless steel container. After that, the container was irradiated by Co-60 source with $1.25 \mathrm{MeV}$ gamma ray at $25^{\circ} \mathrm{C}$ for $1007 \mathrm{~h}$ when the absorbed dose rate of each sample was $2.98 \mathrm{kGy} / \mathrm{h}$. After irradiation, the container was moved to a furnace and thermally aged at $90{ }^{\circ} \mathrm{C}$ for $2000 \mathrm{~h}$.

Open circuit potentials (OCPs) of X65 low carbon steel during 82 days' thermal aging were also measured. A twoelectrode system featuring a carbon steel working electrode and a Pt reference electrode was employed. The Pt reference electrode was calibrated at $90{ }^{\circ} \mathrm{C}$ by the saturated calomel electrode as $0.03285 V_{\mathrm{SHE}}$. In this study, the values of OCPs are the same as that of corrosion potentials, and they are not distinguished from each other in the following descriptions.

\subsection{Weight Loss Measurement}

After irradiation and thermal aging, the samples were removed out from the container, and the weight loss of the samples was measured by chemically cleaning in aqueous solution of $\mathrm{HCl}(15 \mathrm{wt} \%)+3.5 \mathrm{~g} / \mathrm{L} \mathrm{C}_{6} \mathrm{H}_{12} \mathrm{~N}_{4}$. The average value of weight loss was calculated from three 
Table 1 Chemical composition of X65 low carbon steel (wt\%)

Table 2 Chemical composition of Gaomiaozi bentonite (wt\%)

\begin{tabular}{llllllllllll}
\hline Carbon steel & $\mathrm{C}$ & $\mathrm{Si}$ & $\mathrm{Mn}$ & $\mathrm{Al}$ & $\mathrm{Cr}$ & $\mathrm{Ni}$ & $\mathrm{Cu}$ & $\mathrm{Nb}$ & $\mathrm{V}$ & $\mathrm{Ti}$ & $\mathrm{Fe}$ \\
\hline $\mathrm{X} 65$ & 0.065 & 0.14 & 1.58 & 0.042 & 0.22 & 0.01 & 0.02 & 0.063 & 0.05 & 0.015 & Bal. \\
\hline
\end{tabular}

\begin{tabular}{lllllllllll}
\hline Bentonite & $\mathrm{SiO}_{2}$ & $\mathrm{Al}_{2} \mathrm{O}_{3}$ & $\mathrm{MgO}$ & $\mathrm{Na}_{2} \mathrm{O}$ & $\mathrm{Fe}_{2} \mathrm{O}_{3}$ & $\mathrm{~K}_{2} \mathrm{O}$ & $\mathrm{CaO}$ & $\mathrm{TiO}_{2}$ & $\mathrm{Cr}_{2} \mathrm{O}_{3}$ & $\mathrm{P}_{2} \mathrm{O}_{5}$ \\
\hline Contents & 71.42 & 17.14 & 3.12 & 2.45 & 2.46 & 1.87 & 1.21 & 0.23 & 0.04 & 0.06 \\
\hline
\end{tabular}

Table 3 Chemical composition of Beishan groundwater (wt\%)

\begin{tabular}{lllllll}
\hline Cations & $\mathrm{Na}^{+}$ & $\mathrm{NH}_{4}{ }^{+}$ & $\mathrm{Ca}^{2+}$ & $\mathrm{K}^{+}$ & $\mathrm{Mg}^{2+}$ & $\mathrm{Sr}^{2+}$ \\
\hline Contents & 1036.01 & 0.12 & 183.13 & 15.95 & 50.40 & 0.72 \\
\hline Anions & $\mathrm{SO}_{4}{ }^{2-}$ & $\mathrm{Cl}^{-}$ & $\mathrm{HCO}_{3}{ }^{-}$ & $\mathrm{NO}_{3}{ }^{-}$ & $\mathrm{F}^{-}$ & $\mathrm{SiO}_{3}{ }^{2-}$ \\
\hline Contents & 941.17 & 1193.26 & 150.92 & 72.61 & 2.27 & 13.82
\end{tabular}

samples. At the same time, the weight loss of thermal aged samples without irradiation was also measured as the data of controlled experiments.

\subsection{Characterization of the Corrosion Scale}

Surface and cross-sectional morphologies of the corrosion scale were characterized by using SEM (FEI XL30 field emission gun). Chemical compositions of the corrosion scale were detected by using EDS.

Element distribution on the cross section of corrosion scale was obtained by using EPMA (Shimadzu Model EPMA-1610). Furthermore, element distribution at the interface of the carbon steel matrix and corrosion scale, i.e., corrosion front, was observed by TEM, and the sample prepared by focused ion beam (FEI Helios NanoLab 600i). EDS line scan and selected area electron diffraction (SAED) were performed by using JEOL 2100 TEM instrument equipped with an EDS system.

Phase type and spatial distribution of the corrosion scale were detected by using the X-ray diffraction beamline (BL14B1) [24] and the hard X-ray micro-focusing beamline (BL15U1) [25] in Shanghai Synchrotron Radiation Facility (SSRF), respectively. In BL14B1, HRXRD was conducted by using $10 \mathrm{keV} \mathrm{X}$-ray in step scanning mode, and the spot size of X-ray was $0.21 \mathrm{~mm}(\mathrm{H}) \times 1.14 \mathrm{~mm}$ (V). The scanning rate was $0.01 \%$, and the scanning range was from $8^{\circ}$ to $70^{\circ}$. In BL15U1, the energy of X-ray was selected as $18 \mathrm{keV}$, and the spot size in focus mode was $2 \mu \mathrm{m}(\mathrm{H}) \times 2 \mu \mathrm{m}(\mathrm{V}) . \mu$-XRD was conducted on the selected area of the cross section. All the results were converted by Bragg' law to match with the $\mathrm{Cu} K-\alpha$ database.

\section{Results}

\subsection{Microstructure of X65 Low Carbon Steel}

Figure 2 shows the microstructure of X65 low carbon steel with a grain size of $\sim 5 \mu \mathrm{m}$, and the microstructure is a mixture of ferrite and pearlite.

\subsection{Corrosion Rate}

Table 4 lists the weight loss $(\Delta m)$, surface areas $(S)$, corrosion rates $(v)$ and standard deviations $(\sigma)$ of the carbon steel samples. The corrosion rates $(v)$ are obtained according to Eq. (1) [26, 27] and the standard deviations $(\sigma)$ are calculated according to Eq. (2):

$v=\left(m_{0}-m\right) / \rho S t=\Delta m / \rho S t$,

$\sigma=\left[\left(v_{1}-v_{\mathrm{avg}}\right)^{2}+\left(v_{2}-v_{\mathrm{avg}}\right)^{2}+\left(v_{3}-v_{\mathrm{avg}}\right)^{2} / 2\right]^{1 / 2}$,

where $m_{0}$ is the mass of the samples before immersion test, $m$ is the mass of the samples after acid stripping, $\rho$ is the density of carbon steel $\left(7.85 \mathrm{~g} / \mathrm{cm}^{2}\right), \mathrm{t}$ is the time of the thermal aging test, and $\sigma$ is the standard deviation of corrosion rate. As listed in Table 4, the average corrosion rate

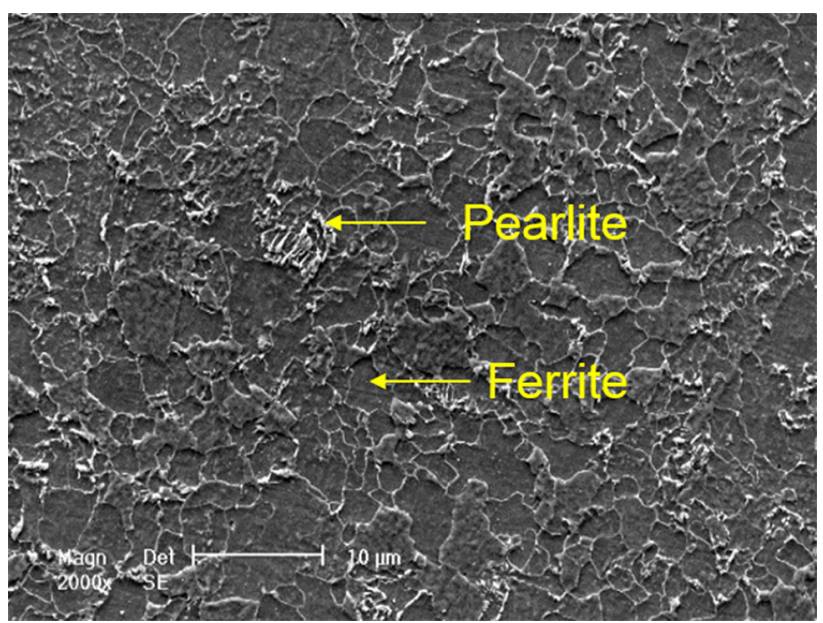

Fig. 2 The microstructure of X65 by SEM including ferrite and pearlite 
Table 4 Weight loss and corrosion rates of X65 low carbon steel

\begin{tabular}{|c|c|c|c|c|c|c|c|c|c|c|c|}
\hline \multirow[t]{2}{*}{$\begin{array}{l}\text { Gamma irradiation } \\
\text { dose rates }\end{array}$} & \multicolumn{3}{|c|}{ Weight loss (g) } & \multicolumn{3}{|c|}{ Surface areas $\left(\mathrm{cm}^{2}\right)$} & \multicolumn{3}{|c|}{$\begin{array}{l}\text { Corrosion rates }(\mu \mathrm{m} / \\
\text { year) }\end{array}$} & \multirow{2}{*}{$\begin{array}{l}\text { Average rates } \\
(\mu \mathrm{m} / \text { year }) \\
v_{\text {avg }}\end{array}$} & \multirow{2}{*}{$\begin{array}{l}\text { Standard deviations } \\
(\mu \mathrm{m} / \text { year }) \\
\sigma\end{array}$} \\
\hline & $\Delta m_{1}$ & $\Delta m_{2}$ & $\Delta m_{3}$ & $S_{1}$ & $S_{2}$ & $S_{3}$ & $v_{1}$ & $v_{2}$ & $v_{3}$ & & \\
\hline $0 \mathrm{kGy} / \mathrm{h}$ & 0.0168 & 0.0173 & 0.0162 & 2.6531 & 2.7053 & 2.6836 & 35.91 & 36.26 & 34.23 & 35.47 & 1.38 \\
\hline 2.98 kGy/h & 0.0229 & 0.0216 & 0.0218 & 2.7607 & 2.7705 & 2.7753 & 46.92 & 44.12 & 44.44 & 45.16 & 1.53 \\
\hline
\end{tabular}

of X65 carbon steel exposed to gamma irradiation and thermal aging is $(45.16 \pm 1.53) \mu \mathrm{m} /$ year and that of X65 carbon steel exposed to identical thermal aging without gamma irradiation is $(35.47 \pm 1.38) \mu \mathrm{m} /$ year.

\subsection{Surface Morphologies and Chemical Compositions}

Figure 3 a reveals the surface morphologies of the corrosion products on the surface of X65 low carbon steel including lighter and darker regions. The lighter region is composed of lamellar slices (Fig. 3b) and the darker region is composed of blocky particles (Fig. 3c). Some protuberant zones are also found on the surface presenting as amorphous swellings (Fig. 3d). Table 5 lists chemical compositions of these products showing that the corrosion products are mainly composed of $\mathrm{Fe}$ and $\mathrm{O}$. The lamellar slices and the amorphous swellings are $\mathrm{O}$ concentrated, the blocky particles are Fe concentrated, and the amorphous swellings possess higher percentage of $\mathrm{Si}, \mathrm{Mg}$, and $\mathrm{Al}$.

\subsection{Cross-Sectional Morphologies and Elemental Distribution}

Figure $4 \mathrm{a}$ illustrates the cross-sectional morphologies of corrosion scale formed on the surface of X65 low carbon
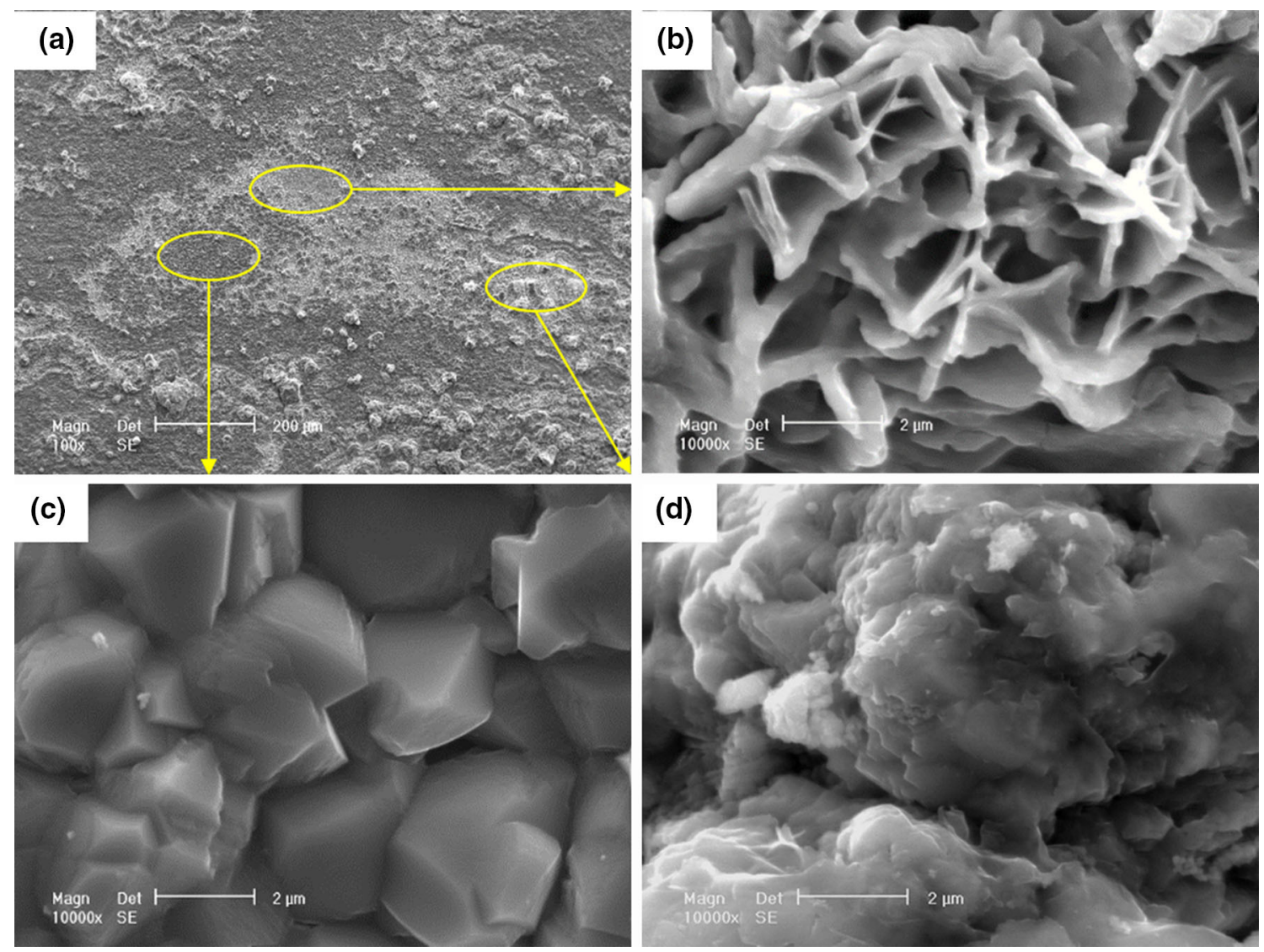

Fig. 3 Surface morphologies of corrosion scale formed on X65 low carbon steel: a macro-morphology, b lamellar slices, $\mathbf{c}$ blocky particles, d amorphous swellings 
Table 5 Chemical composition of the corrosion scales with different morphology (at.\%)

\begin{tabular}{lllllllll}
\hline Species & $\mathrm{Fe}$ & $\mathrm{O}$ & $\mathrm{Si}$ & $\mathrm{Ca}$ & $\mathrm{Mg}$ & $\mathrm{Al}$ & $\mathrm{Na}$ & $\mathrm{Mn}$ \\
\hline Lamellar slices & 39.59 & 56.36 & 0.98 & 0.39 & 0.56 & 0.49 & 0.51 & 1.14 \\
Blocky particles & 56.04 & 41.23 & 0.94 & 0.25 & 0.22 & 0.29 & 0.25 & 0.78 \\
Amorphous swellings & 36.08 & 55.16 & 2.12 & 0.62 & 1.39 & 2.50 & 0.35 & 1.82 \\
\hline
\end{tabular}
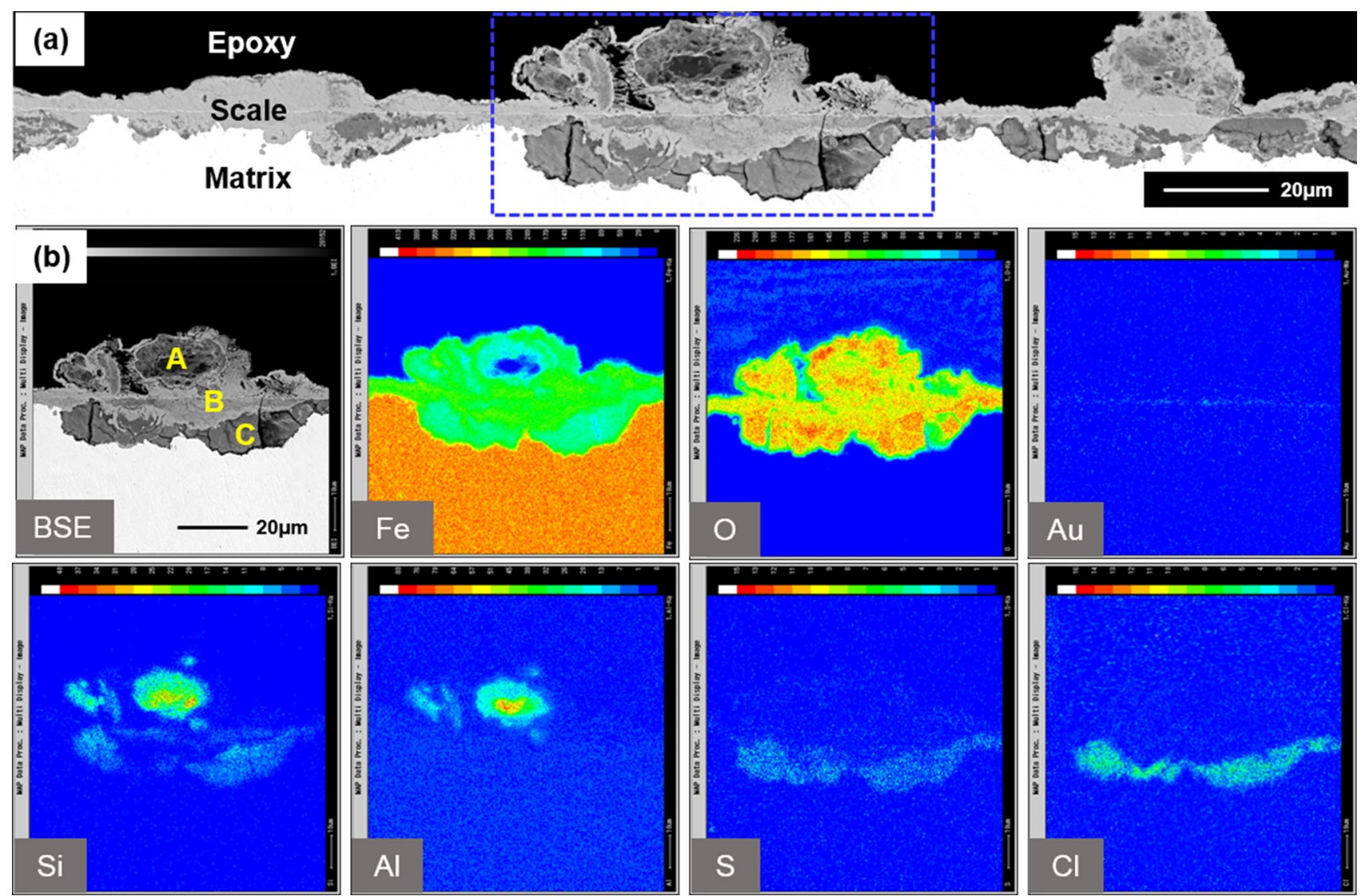

Fig. 4 a Cross-sectional morphologies of the corrosion scale formed on X65 low carbon steel, b EPMA elemental distribution maps of the area marked by the dashed line rectangle in a

steel. An intact corrosion scale forms on the carbon steel matrix, but the thickness of corrosion scale is non-uniform. A straight bright line in Fig. 4a represents the original surface, and the corrosion scale is divided into two layers. Figure $4 \mathrm{~b}$ shows the element distribution around part of the cross section in Fig. 4a marked with dashed line rectangle. $\mathrm{Au}$ is concentrated along the bright line mentioned above, and it demonstrates that the line can represent the original surface which has been marked by Au particles before the immersion test. Fe and $\mathrm{O}$ are homogeneously distributed in the corrosion scale. $\mathrm{Si}, \mathrm{S}$, and $\mathrm{Cl}$ are concentrated around the corrosion front in the inner layer scale, while Si and $\mathrm{Al}$ are concentrated in the outer layer scale.

For further investigating the element distribution at the corrosion front, a micro-cross section sample approximate $3 \mu \mathrm{m}$ in length was prepared by focused ion beam at the interface of the carbon steel matrix and scale. Figure $5 \mathrm{a}$ presents the TEM bright-field image of this cross section consisting of carbon steel matrix, inner part scale, and outer part scale. Figure 5b illustrates EDS line scan profiles along the dashed line in Fig. 5a. Element contents in the carbon steel matrix are homogeneous. However, the contents of $\mathrm{Si}, \mathrm{S}$, and $\mathrm{Cl}$ increase from the outer part scale to inner part scale gradually, and they reach maximum values around the interface of matrix and inner part scale. Figure $5 c$ reveals SAED of different from the micro-cross section. The matrix is $\mathrm{Fe}$, the inner part scale is amorphous solid, and the outer part scale is polycrystalline of $\mathrm{Fe}_{3} \mathrm{O}_{4}$ and $\mathrm{FeCO}_{3}$.

\subsection{Phase Detection of Corrosion Scale}

Figure 6 shows the HRXRD pattern of the corrosion scale formed on the surface of X65 low carbon steel. The 

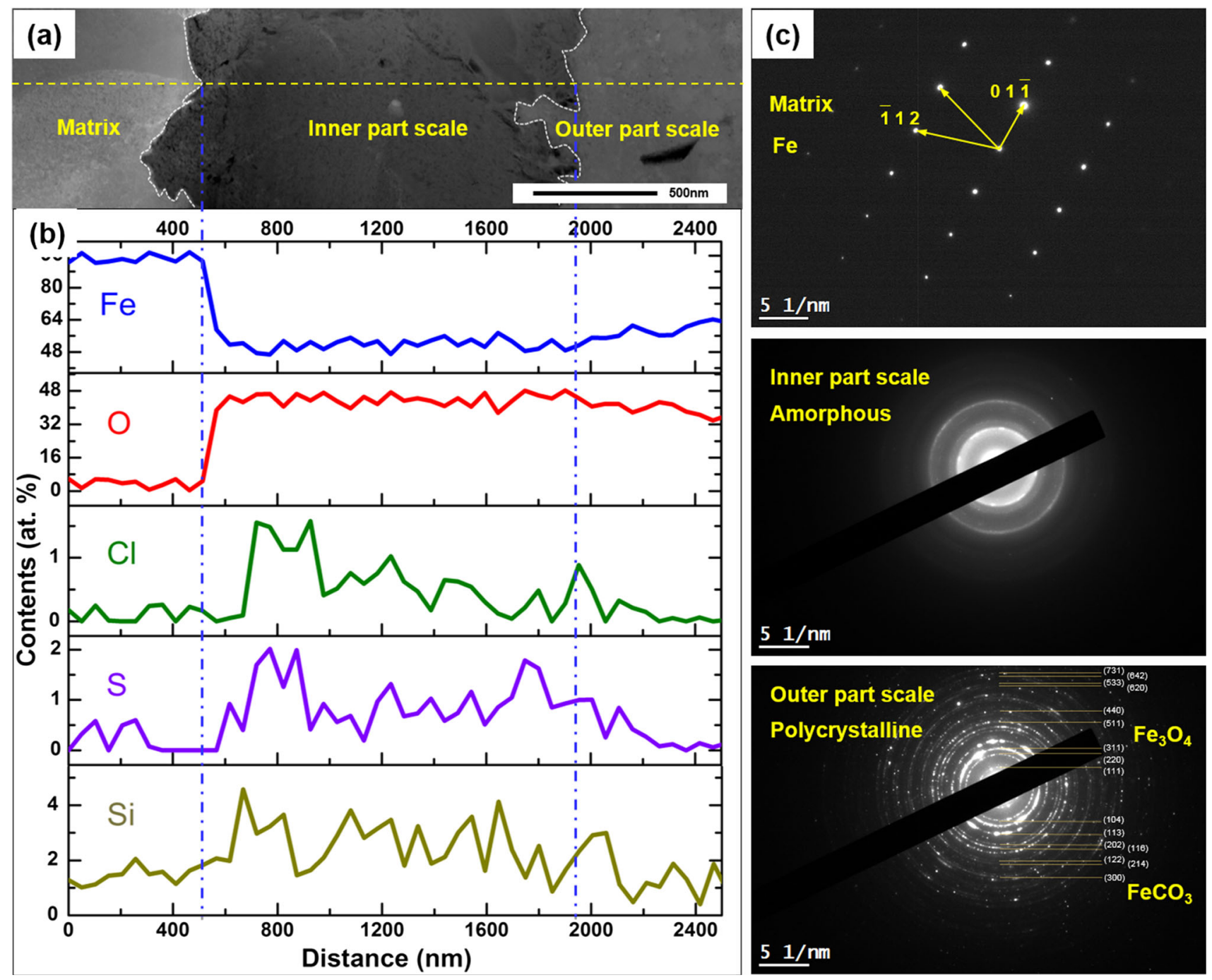

Fig. 5 a Bright-field image of cross section at corrosion front of X65 low carbon steel, b EDS line scan profiles alone the dashed line in a, c SAED for matrix, inner part scales, and outer part scale

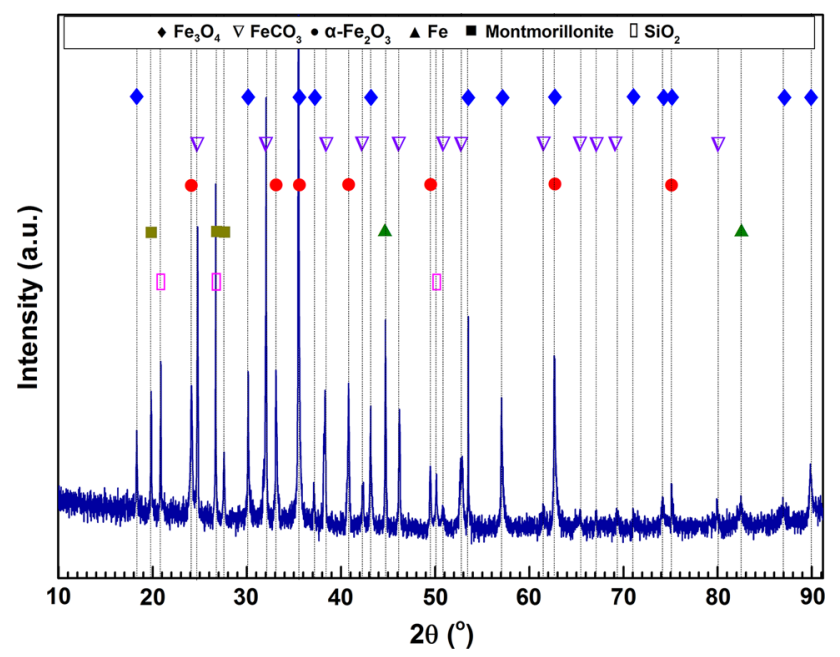

Fig. 6 HRXRD pattern of the corrosion scale formed on X65 low carbon steel corrosion scale is mainly composed of $\mathrm{Fe}_{3} \mathrm{O}_{4}, \mathrm{FeCO}_{3}, \alpha$ $\mathrm{Fe}_{2} \mathrm{O}_{3},(\mathrm{Na}, \mathrm{Ca})_{0.3}(\mathrm{Al}, \mathrm{Mg})_{2} \mathrm{Si}_{4} \mathrm{O}_{10}(\mathrm{OH})_{2} \cdot n \mathrm{H}_{2} \mathrm{O}$ (montmorillonite), $\mathrm{SiO}_{2}$, and $\mathrm{Fe}$ (matrix). Montmorillonite and $\mathrm{SiO}_{2}$ are the main compositions of bentonite confined in the corrosion scale.

Figure 7a-c shows $\mu$-XRD patterns of typical regions in Fig. $4 \mathrm{~b}$ marked with $\mathrm{A}, \mathrm{B}$, and $\mathrm{C}$, respectively. Region $\mathrm{A}$ is composed of $\mathrm{Fe}_{3} \mathrm{O}_{4}, \mathrm{FeCO}_{3}$, montmorillonite, $\mathrm{SiO}_{2}$, and $\mathrm{Fe}$. Region B is composed of $\mathrm{Fe}_{3} \mathrm{O}_{4}$ and $\mathrm{Fe}$. Region $\mathrm{C}$ is composed of $\mathrm{Fe}_{3} \mathrm{O}_{4}, \mathrm{FeCO}_{3}$, and, Fe. Combining the results of element distribution and $\mu-\mathrm{XRD}$, a schematic diagram of the phase distribution is illustrated Fig. 7d. Taking the original surface as boundary, the corrosion scale is divided into the internal dense product layer (internal DPL) and the external dense product layer (external DPL). The internal DPL is mainly composed of $\mathrm{Fe}_{3} \mathrm{O}_{4}$ with segregated $\mathrm{FeCO}_{3}$ at the corrosion front. The external DPL is mainly 

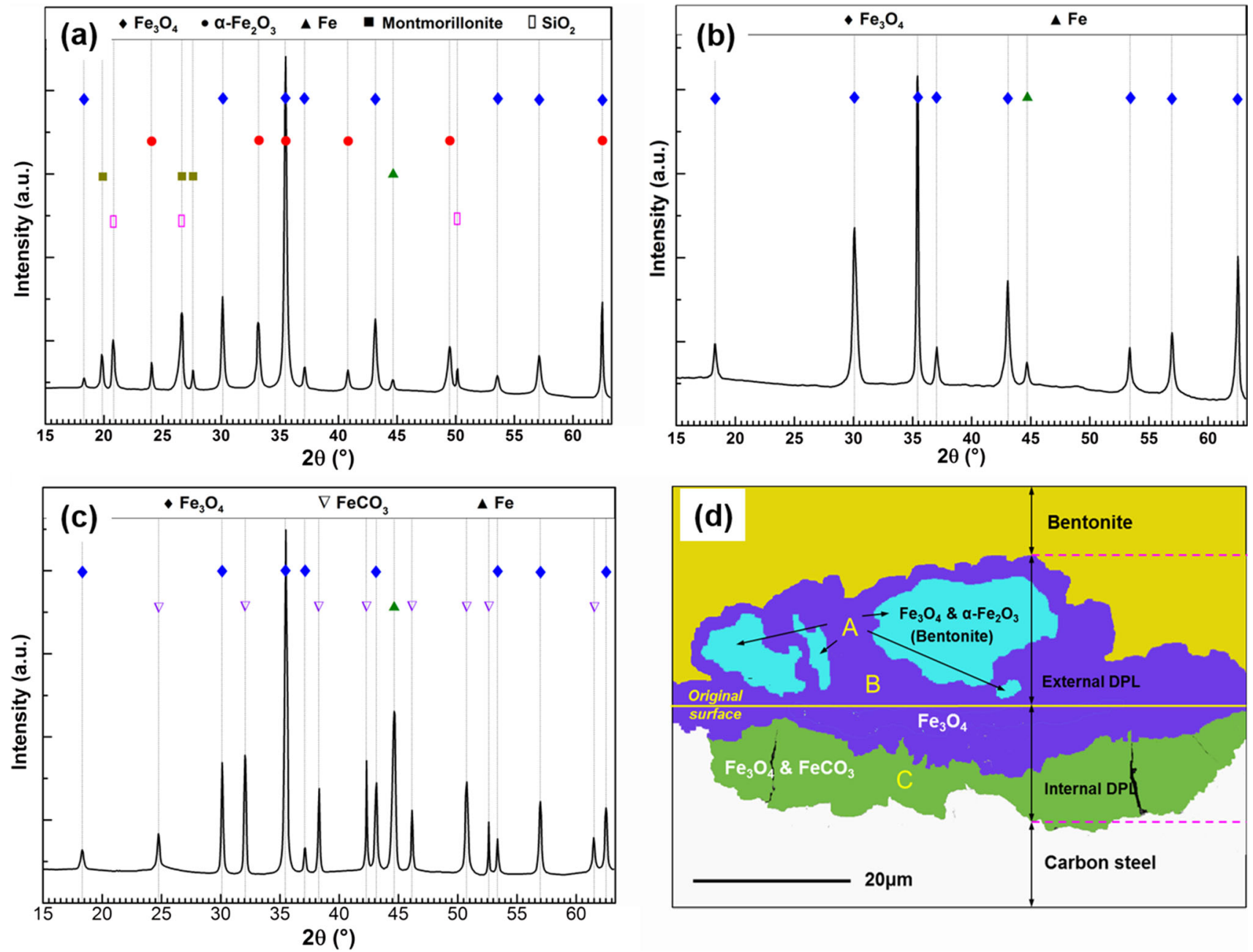

Fig. 7 a-c $\mu$-XRD spectra on the cross section of the corrosion scales formed on X65, $\mathbf{d}$ schematic diagram of the phase distribution on the cross section

composed of $\mathrm{Fe}_{3} \mathrm{O}_{4}$ with segregated $\alpha-\mathrm{Fe}_{2} \mathrm{O}_{3}$ and bentonite at some relics.

\section{Discussion}

\subsection{Aerobic Corrosion Rate of the Carbon Steel}

The average aerobic corrosion rate of X65 low carbon steel in Gaomiaozi bentonite containing $17 \mathrm{wt} \%$ Beishan groundwater exposed to gamma irradiated and thermal aging is $(45.16 \pm 1.53) \mu \mathrm{m} /$ year. It is timely higher than the corrosion rate of carbon steel in anaerobic MX-80 and Callovo-Oxfordian clay as 3-20 $\mu \mathrm{m} /$ year [15-19]. King et al. [28] claimed that $\mathrm{O}_{2}$ diffusion controlled the corrosion rates of the carbon steel in bentonite. Therefore, higher $\mathrm{O}_{2}$ concentration in this study can be the primary reason for this corrosion rate acceleration. Previous study [29] found that $2.98 \mathrm{kGy} / \mathrm{h}$ gamma irradiation accelerated the aerobic corrosion rate of X65 low carbon steel in bentonite by $33 \%$ during 120 days' test. It indicated that gamma irradiation should be another important reason for the rate acceleration. Controlled experiments exposed to identical thermal aging for 82 days without gamma irradiation have been conducted in this study for demonstrating the effect of gamma irradiation. The average corrosion rate of controlled experiments is $(35.47 \pm 1.38) \mu \mathrm{m} /$ year. It means that gamma irradiation accelerates the corrosion rate by $27 \%$ which coincide with the results of previous study.

\subsection{Element Distribution at the Cross Section}

As mentioned in Sect. 3.4, element segregations are observed on the cross section of the carbon steel corrosion products. The $\mathrm{Si}, \mathrm{S}$, and $\mathrm{Cl}$ concentrations at the inner layer scale may be resulted from the anion of Beishan groundwater. As listed in Table $3, \mathrm{SO}_{4}{ }^{2-}$ and $\mathrm{Cl}^{-}$are the two main anions in Beishan groundwater. They can be attracted 

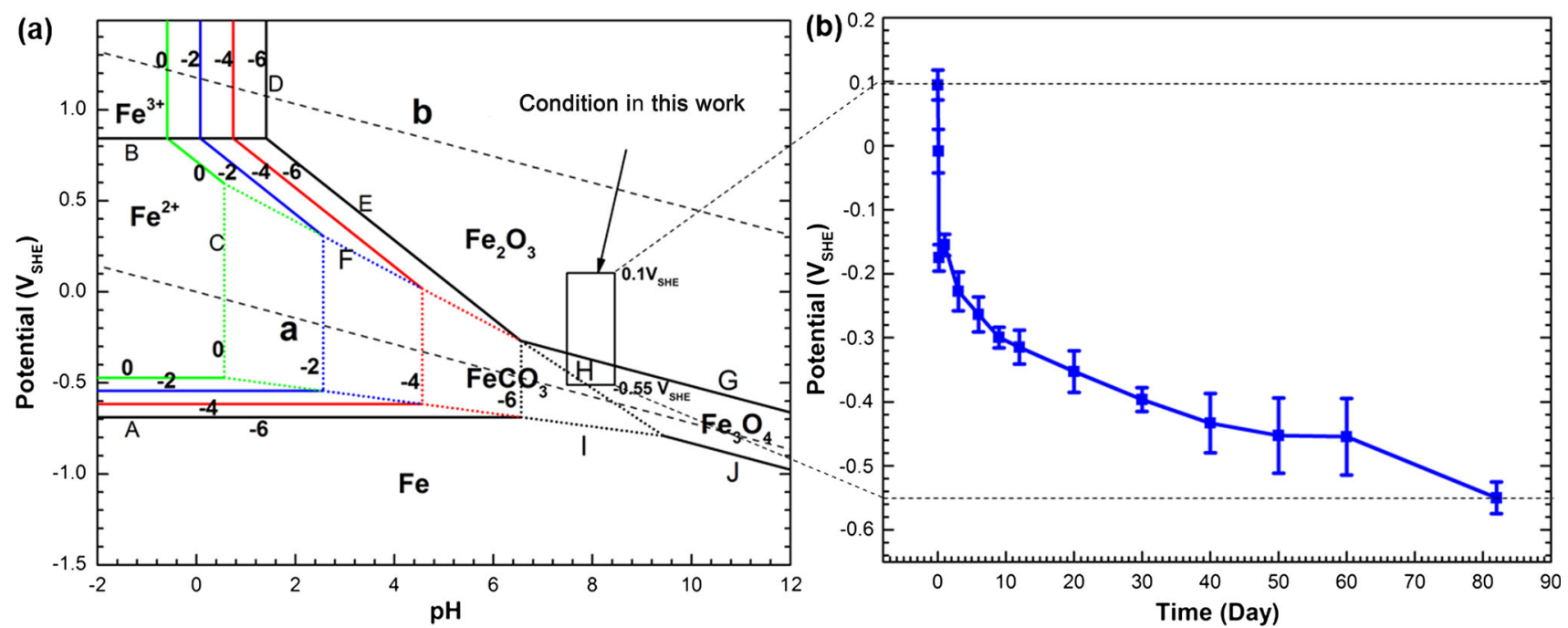

Fig. 8 a E-pH diagram of $\mathrm{Fe}-\mathrm{HCO}_{3}{ }^{-}-\mathrm{H}_{2} \mathrm{O}$ at $90{ }^{\circ} \mathrm{C}$, b OCPs for the electrochemical samples during 82 days' thermal aging

by redundant $\mathrm{Fe}^{2+}$ cations during rapid anodic dissolution process [30]. Figure $4 \mathrm{~b}$ shows that the regions with $\mathrm{S}$ and $\mathrm{Cl}$ concentrations are exactly at the corrosion front of pitting sites. EDS line scan at the corrosion front shows that the contents of $\mathrm{S}$ and $\mathrm{Cl}$ cumulatively increase from the outer part scale to the inner part scale and reach maximum values around the interface of inner part scale and matrix. It means that the rapid anodic dissolution at the corrosion front of the pitting sites accelerates the diffusion processes of $\mathrm{SO}_{4}{ }^{2-}$ and $\mathrm{Cl}^{-}$. In return, $\mathrm{SO}_{4}{ }^{2-}$ and $\mathrm{Cl}^{-}$can accelerate pitting initiation process [31-33]. Therefore, the accumulation of $\mathrm{S}$ and $\mathrm{Cl}$ at corrosion front is autocatalytic. Similarly, the concentration of Si may be induced by the diffusion process of $\mathrm{SiO}_{3}{ }^{2-}$ in Beishan groundwater, although the possibility of $\mathrm{SiO}_{2}$ inclusions from bentonite has not been excluded.

The $\mathrm{Si}$ and $\mathrm{Al}$ concentrations at the outer layer scale may be attributed to the bentonite inclusions as $\mathrm{SiO}_{2}$ and $\mathrm{Al}_{2} \mathrm{O}_{3}$ are main components of Gaomiaozi bentonite. It has been demonstrated by HRXRD pattern with the diffraction peaks of montmorillonite and $\mathrm{SiO}_{2}$. Martin et al. [15] announced that the corrosion products of low-alloyed steels in contact with Bure clay included some Fe-rich phyllosilicate as illite is main component of the Bure clay. It indicates that montmorillonite modified by $\mathrm{Fe}^{3+}$ and $\mathrm{Fe}^{2+}$ could also be found in this work instead of simply physical mixture of montmorillonite and iron oxides, although the discrepancy between montmorillonite and Fe-rich montmorillonite has not been detected. Thus, the hyperfine structure of the corrosion products should be analyzed in the further investigation.

\subsection{Phase Distribution at the Cross Section}

The corrosion scales formed on the surface of X65 low carbon steel are mainly composed of $\mathrm{Fe}_{3} \mathrm{O}_{4}, \mathrm{FeCO}_{3}, \alpha$ $\mathrm{Fe}_{2} \mathrm{O}_{3}$, montmorillonite, and $\mathrm{SiO}_{2}$. Hydroxides have not been detected which is different from the carbon steel corrosion products generated at room temperature [34]. $\mu$ XRD patterns show that $\mathrm{Fe}_{3} \mathrm{O}_{4}$ is evenly distributed around the corrosion scales, $\mathrm{FeCO}_{3}$ segregates at the corrosion front, and $\alpha-\mathrm{Fe}_{2} \mathrm{O}_{3}$ and bentonite segregate at some relics. In order to explain the formation mechanism of these phase distributions, E-pH diagram of $\mathrm{Fe}-\mathrm{HCO}_{3}{ }^{-}-\mathrm{H}_{2} \mathrm{O}$ at $90{ }^{\circ} \mathrm{C}$ was calculated in "Appendix," and shown in Fig. 8a. It can be seen that the predicted stable phases contain $\mathrm{Fe}_{3} \mathrm{O}_{4}$, $\mathrm{Fe}_{2} \mathrm{O}_{3}$, and $\mathrm{FeCO}_{3}$ which coincide with the detected phases in Figs. 6 and 7.

During the thermal aging test of the irradiated X65 low carbon steel and bentonite, OCPs of X65 low carbon steel are decreased from $0.10 V_{\mathrm{SHE}}$ to $-0.55 V_{\mathrm{SHE}}$. Therefore, the testing condition in this work should be defined by lines $\mathrm{pH}=7.56, \mathrm{pH}=8.53, E=0.1 V_{\mathrm{SHE}}$, and $E=-0.55 V_{\mathrm{SHE}}$. As shown in Fig. 8a, these testing conditions overlap with each stable region of $\mathrm{Fe}_{3} \mathrm{O}_{4}, \mathrm{Fe}_{2} \mathrm{O}_{3}$, and $\mathrm{FeCO}_{3}$.

At the beginning of thermal aging test, the corrosion potential is relatively high, and $\mathrm{Fe}_{2} \mathrm{O}_{3}$ is likely to be generated. After dozens of days, the corrosion potential decreases to the stable region of $\mathrm{Fe}_{3} \mathrm{O}_{4}$ with the depletion of $\mathrm{O}_{2}$, and $\mathrm{Fe}_{2} \mathrm{O}_{3}$ is inclined to be degenerated. It is the reason why external DPL is mainly composed of $\mathrm{Fe}_{3} \mathrm{O}_{4}$, and $\mathrm{Fe}_{2} \mathrm{O}_{3}$ is only segregated at some relics. Meanwhile, $\mathrm{Fe}_{2} \mathrm{O}_{3}$ has disappeared in the internal DPL beneath the original surface when $\mathrm{O}_{2}$ is deficient. According to the E-pH diagram, when the reducing condition is formed, $\mathrm{FeCO}_{3}$ is likely to be generated at relatively low $\mathrm{pH}$ 


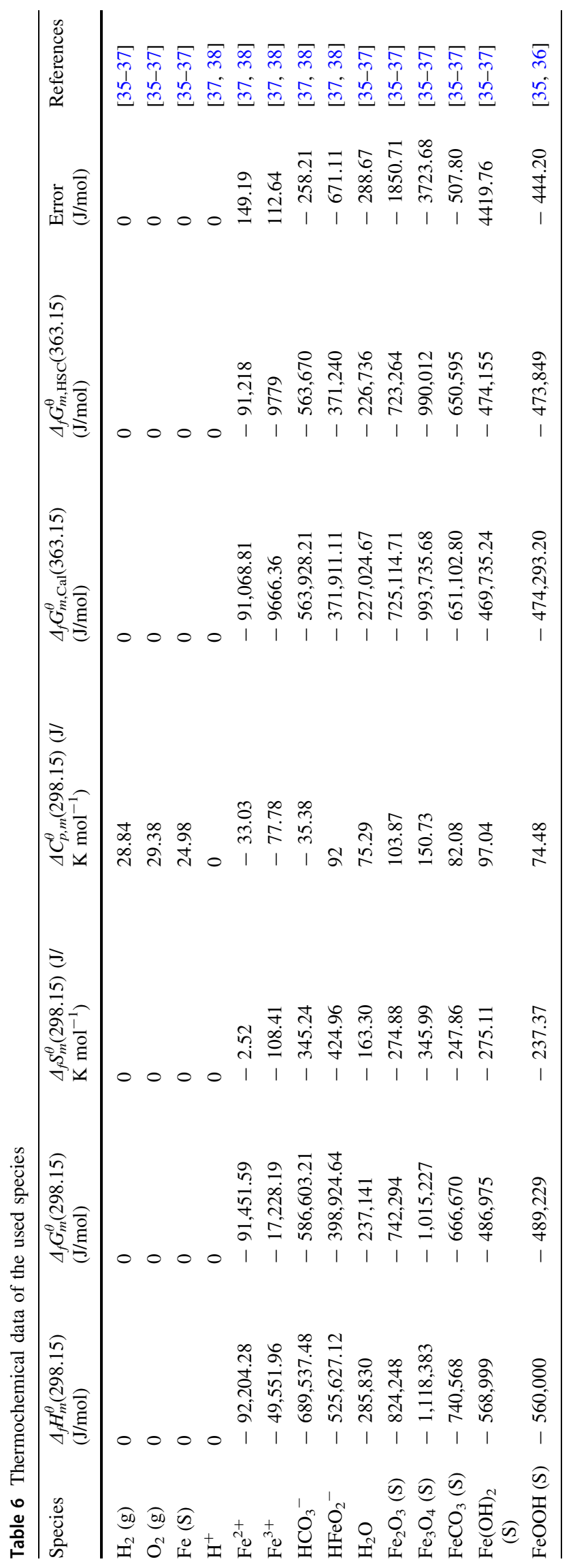


Table 7 Chemical reactions and the corresponding equilibrium equations for the boundaries between the used species

\begin{tabular}{|c|c|c|}
\hline Number & Chemical reactions $[37,38,40]$ & Equilibrium equations \\
\hline a & $2 \mathrm{H}^{+}+2 \mathrm{e}^{-}=\mathrm{H}_{2}$ & $E_{a}=-0.0721 \mathrm{pH}$ \\
\hline $\mathrm{b}$ & $\mathrm{O}_{2}+4 \mathrm{H}^{+}+4 \mathrm{e}^{-}=2 \mathrm{H}_{2} \mathrm{O}$ & $E_{b}=1.1765-0.0721 \mathrm{pH}$ \\
\hline A & $\mathrm{Fe}^{2+}+2 \mathrm{e}^{-}=\mathrm{Fe}$ & $E_{A}=-0.4719+0.0360 \lg \left[\mathrm{Fe}^{2+}\right]$ \\
\hline B & $\mathrm{Fe}^{3+}+\mathrm{e}^{-}=\mathrm{Fe}^{2+}$ & $E_{B}=0.8437+0.0721\left\{\lg \left[\mathrm{Fe}^{3+}\right]-\lg \left[\mathrm{Fe}^{2+}\right]\right\}$ \\
\hline $\mathrm{C}$ & $\mathrm{FeCO}_{3}+\mathrm{H}^{+}=\mathrm{Fe}^{2+}+\mathrm{HCO}_{3}^{-}$ & $\lg \left[\mathrm{Fe}^{2+}\right]+\lg \left[\mathrm{HCO}_{3}^{-}\right]=0.5601-\mathrm{pH}$ \\
\hline $\mathrm{D}$ & $\mathrm{Fe}_{2} \mathrm{O}_{3}+6 \mathrm{H}^{+}=2 \mathrm{Fe}^{3+}+3 \mathrm{H}_{2} \mathrm{O}$ & $\lg \left[\mathrm{Fe}^{3+}\right]=-1.7770-3 \mathrm{pH}$ \\
\hline $\mathrm{E}$ & $\mathrm{Fe}_{2} \mathrm{O}_{3}+6 \mathrm{H}^{+}+2 \mathrm{e}^{-}=2 \mathrm{Fe}^{2+}+3 \mathrm{H}_{2} \mathrm{O}$ & $E_{E}=0.7156-0.2163 \mathrm{pH}-0.0721 \lg \left[\mathrm{Fe}^{2+}\right]$ \\
\hline $\mathrm{F}$ & $\mathrm{Fe}_{2} \mathrm{O}_{3}+2 \mathrm{HCO}_{3}{ }^{-}+4 \mathrm{H}^{+}+2 \mathrm{e}^{-}=2 \mathrm{FeCO}_{3}+3 \mathrm{H}_{2} \mathrm{O}$ & $E_{F}=0.6753-0.1442 \mathrm{pH}+0.0721 \lg \left[\mathrm{HCO}_{3}^{-}\right]$ \\
\hline $\mathrm{G}$ & $3 \mathrm{Fe}_{2} \mathrm{O}_{3}+2 \mathrm{H}^{+}+2 \mathrm{e}^{-}=2 \mathrm{Fe}_{3} \mathrm{O}_{4}+\mathrm{H}_{2} \mathrm{O}$ & $E_{G}=0.2029-0.0721 \mathrm{pH}$ \\
\hline $\mathrm{H}$ & $\mathrm{Fe}_{3} \mathrm{O}_{4}+3 \mathrm{HCO}_{3}^{-}+5 \mathrm{H}^{+}+2 \mathrm{e}^{-}=3 \mathrm{FeCO}_{3}+4 \mathrm{H}_{2} \mathrm{O}$ & $E_{H}=0.9115-0.1803 \mathrm{pH}+0.1082 \lg \left[\mathrm{HCO}_{3}{ }^{-}\right]$ \\
\hline I & $\mathrm{FeCO}_{3}+\mathrm{H}^{+}+2 \mathrm{e}^{-}=\mathrm{Fe}+\mathrm{HCO}_{3}^{-}$ & $E_{I}=-0.4518-0.0360 \mathrm{pH}-0.0360 \lg \left[\mathrm{HCO}_{3}{ }^{-}\right]$ \\
\hline $\mathrm{J}$ & $\mathrm{Fe}_{3} \mathrm{O}_{4}+8 \mathrm{H}^{+}+8 \mathrm{e}^{-}=3 \mathrm{Fe}+4 \mathrm{H}_{2} \mathrm{O}$ & $E_{J}=-0.1109-0.0721 \mathrm{pH}$ \\
\hline
\end{tabular}

condition. Wang et al. [30] indicated that the $\mathrm{pH}$ at localized corrosion site was prone to be lower. It could be the reason why $\mathrm{FeCO}_{3}$ segregates at the corrosion front of localized corrosion. Furthermore, SAED from the sample at corrosion front also demonstrates the existence of $\mathrm{FeCO}_{3}$.

\section{Conclusion}

In this work, $2.98 \mathrm{kGy} / \mathrm{h}(1007 \mathrm{~h})$ gamma irradiation and $90{ }^{\circ} \mathrm{C}(2000 \mathrm{~h})$ thermal aging were exerted to X65 grade low carbon steel buried in Gaomiaozi bentonite containing $17 \mathrm{wt} \%$ Beishan groundwater. The aerobic corrosion behavior of X65 grade low carbon steel was investigated by using weight loss measurement, SEM/EDS, EPMA, TEM, HRXRD, and $\mu$-XRD. The following conclusions can be made:

1. The average aerobic corrosion rate of carbon steel is $(45.16 \pm 1.53) \mu \mathrm{m} /$ year.

2. Taking the original surface as boundary, the corrosion scale is divided into internal DPL mainly composed of $\mathrm{Fe}_{3} \mathrm{O}_{4}$ with segregated $\mathrm{FeCO}_{3}$ at the corrosion front and external DPL mainly composed of $\mathrm{Fe}_{3} \mathrm{O}_{4}$ with segregated $\alpha-\mathrm{Fe}_{2} \mathrm{O}_{3}$ and bentonite at some relics.

3. $\mathrm{Si}, \mathrm{S}$, and $\mathrm{Cl}$ are concentrated around the corrosion front in the internal DPL, while $\mathrm{Si}$ and $\mathrm{Al}$ are concentrated in the external DPL.

Acknowledgements This work was supported by Key Research Program of Frontier Sciences, Chinese Academy of Sciences (QYZDYSSWJSC012); the National Natural Science Foundation of China (No. 51771211); the National Key Research and Development Program of
China (2017YFB0702100, 2016YFE0105200); and Key Program of the Chinese Academy of Sciences (ZDRW-CN-2017-1).

\section{Appendix}

The values of the standardly molar enthalpy changes, entropy changes, and Gibbs free energy changes at a high temperature, $\Delta_{f} H_{m}^{\theta}(T), \Delta_{f} S_{m}^{\theta}(T)$, and $\Delta_{f} G_{m}^{\theta}(T)$, were calculated using Eqs. (3-5) [35-37]:

$$
\begin{aligned}
& \Delta_{f} H_{m}^{\theta}(T)=\Delta_{f} H_{m}^{\theta}(298)+\int_{298}^{T} \Delta C_{p, m}(T) \mathrm{d} T, \\
& \Delta_{f} S_{m}^{\theta}(T)=\Delta_{f} S_{m}^{\theta}(298)+\int_{298}^{T} \Delta C_{p, m}(T) / T \mathrm{~d} T, \\
& \Delta_{f} G_{m}^{\theta}(T)=\Delta_{f} H_{m}^{\theta}(T)-T \Delta_{f} S_{m}^{\theta}(T) .
\end{aligned}
$$

When the temperature was not very high, the molar heat capacity changes, $\Delta C_{p}, m$, could be regarded as constant in the calculation, and then, $\Delta_{f} G_{m}^{\theta}(T)$ was calculated using Eq. (6) $[37,38]$ :

$$
\begin{aligned}
\Delta_{f} G_{m}^{\theta}(T)= & \Delta_{f} G_{m}^{\theta}(298) \\
& +\Delta C_{p, m}(298)(T-298-T \ln T / 298) \\
& -(T-298) \Delta_{f} S_{m}^{\theta}(298) .
\end{aligned}
$$

Table 6 lists the thermodynamic data of each chemical species [35-39] calculated by the aforementioned method, and the results are in agreement with the data calculated by HSC 6.0 software.

The molarities of $\mathrm{Fe}^{2+}$ and $\mathrm{Fe}^{3+}$ are selected as $10^{-6}$, $10^{-4}, 10^{-2}$, and $1 \mathrm{~mol} / \mathrm{L}$ successively, and the molarity of $\mathrm{HCO}_{3}{ }^{-}$is supposed to be $1 \mathrm{~mol} / \mathrm{L}$ for simulating the elemental concentration. Table 7 presents the chemical reactions [38, 40] used in the calculations and the 
corresponding equilibrium equations calculated by Nernst's Eq. (7) [38]:

$$
\begin{aligned}
E(T) & =E^{\theta}(T)+\left[\ln \left(C_{O} / C_{R}\right)\right] R T / n F \\
& =-\Delta_{f} G_{m}^{\theta} / n F+\left[\ln \left(C_{O} / C_{R}\right)\right] R T / n F .
\end{aligned}
$$

\section{References}

[1] J. Wang, G.Q. Xu, H.L. Zheng, X.H. Fan, C.Z. Wang, Z.W. Fan, World Nucl. Geosci. 22, 5 (2005)

[2] H.L. Wang, Dissertation (Beijing Research Institute of Uranium Geology, 2014)

[3] D.G. Bennett, R. Gens, J. Nucl. Mater. 379, 1 (2008)

[4] B.W.A. Sherar, P.G. Keech, D.W. Shoesmith, Corros. Sci. 53, $3636(2011)$

[5] B.W.A. Sherar, P.G. Keech, D.W. Shoesmith, Corros. Sci. 53, 3643 (2011)

[6] K. Ishiguro, K. Kawamura, H. Sonobe, M. Nodaka, T. Arai, Y. Yusa, N. Tsunoda, Nucl. Sci. Eng. 116, 61 (1989)

[7] W. Debruyn, Corrosion of Container Materials Under Clay Repository Conditions, 10121 (Atomic Energy of Canada Limited, Belgium, 1990), p. 175

[8] J.L. Nelson, R.E. Westerman, F.S. Gerber, Mater. Res. Soc. Symp. Proc. 26, 121 (1984)

[9] F. King, C. Lilja, K. Pedersen, P. Pitkanen, M. Vahanen, An Update of the State of the Art Report on the Corrosion of Copper Under Expected Conditions in a Deep Geologic Repository, TR10-67 (Svensk Kärnbränslehantering AB, Stockholm, 2010), p. 91

[10] F. King, M. Kolar, P.G. Keech, Corros. Eng. Sci. Technol. 49, $455(2014)$

[11] D. Féron, D. Crusset, J.M. Gras, J. Nucl. Mater. 379, 16 (2008)

[12] H12: Project to Establish the Scientific and Technical Basis for HLW Disposal in Japan, TN1410-2000-001 (Japan Nuclear Cycle Development Institute, 2000), p. 4-14

[13] F. King, C. Padovani, Corros. Eng. Sci. Technol. 46, 82 (2011)

[14] K. Lundgren, Radiation Levels and Absorbed Doses Around Copper Canisters Containing Spent LWR Fuel, TR-82-11 (Svensk Kärnbränslehantering AB, Stockholm, 1982), p. 20

[15] F.A. Martin, C. Bataillon, M.L. Schlegel, J. Nucl. Mater. 379, 80 (2008)

[16] F. Martin, S. Perrin, M. Fenart, M. Schlegel, C. Bataillon, Corros. Eng. Sci. Technol. 49, 460 (2014)
[17] F.A. Martin, S. Perrin, C. Bataillon, Mater. Res. Soc. Symp. Proc. 1475, 471 (2012)

[18] M.L. Schlegel, C. Bataillon, K. Benhamida, C. Blanc, D. Menut, J.L. Lacour, Appl. Geochem. 23, 2619 (2008)

[19] M.L. Schlegel, C. Bataillon, C. Blanc, D. Pret, E. Foy, Environ. Sci. Technol. 44, 1503 (2010)

[20] D. Neff, S. Reguer, L. Bellot-Gurlet, P. Dillmann, R. Bertholon, J. Raman Spectrosc. 35, 739 (2004)

[21] D. Neff, P. Dillmann, L. Bellot-Gurlet, G. Beranger, Corros. Sci. 47, 515 (2005)

[22] N.R. Smart, A.P. Rance, L.O. Werme, J. Nucl. Mater. 379, 97 (2008)

[23] A. Honda, T. Teshima, A. Tsurudome, H. Ishikawa, Y. Yusa, N. Sasaki, Mater. Res. Soc. Symp. Proc. 212, 287 (1991)

[24] T.Y. Yang, W. Wen, G.Z. Yin, X.L. Li, M. Gao, Y.L. Gu, L. Li, Y. Liu, H. Lin, X.M. Zhang, B. Zhao, T.K. Liu, Y.G. Yang, Z. Li, X.T. Zhou, X.Y. Gao, Nucl. Sci. Technol. 26, 1 (2015)

[25] L.L. Zhang, S. Yan, S. Jiang, K. Yang, H. Wang, S.M. He, D.X. Liang, L. Zhang, Y. He, X.Y. Lan, C.W. Mao, J. Wang, H. Jiang, Y. Zheng, Z.H. Dong, L.Y. Zeng, A.G. Li, Nucl. Sci. Technol. 26, 0601011 (2015)

[26] C. Lai, X.M. Li, L.K. Zou, Q. Chen, B. Xie, Y.L. Li, X.L. Li, Z. Tao, Corros. Sci. 85, 471 (2014)

[27] C. Lai, Z. Xiang, Corros. Sci. 99, 178 (2015)

[28] F. King, Overview of a Carbon Steel Container Corrosion Model for a Deep Geological Repository in Sedimentary Rock, TR 2007-01 (Integrity Corrosion Consulting Limited, New Brunswick, 2007), p. 8

[29] C.S. Liu, J.Q. Wang, Z.M. Zhang, E.H. Han, Corros. Eng. Sci. Technol. 52, 136 (2017)

[30] S.Y. Wang, H.L. Ming, J. Ding, Z.M. Zhang, J.Q. Wang, E.H. Han, A. Atrens, Corros. Sci. 102, 469 (2016)

[31] X. Cao, C.C. Xu, Acta Metall. Sin. (Engl. Lett.) 19, 34 (2006)

[32] S. Hastuty, A. Nishikata, T. Tsuru, Corros. Sci. 52, 2035 (2010)

[33] K. Ogura, T. Ohama, Corrosion 37, 569 (1981)

[34] S.T. Wang, S.W. Yang, K.W. Gao, X.L. He, Acta Metall. Sin. (Engl. Lett.) 21, 425 (2008)

[35] I. Barin, Thermochemical Data of Pure Substances, 3rd edn. (Verlagsgesellschaft mbH, Weinheim, 1995), pp. 1-25

[36] I. Barin, O. Knacke, O. Kubaschewski, Thermochemical Properties of Inorganic Substances (Springer, Berlin, 1977), p. 11

[37] H.E. Townsend, Corros. Sci. 10, 343 (1970)

[38] X. Liu, X. Wu, E.H. Han, Corros. Sci. 53, 3337 (2011)

[39] E.L. Shock, D.C. Sassani, M. Willis, D.A. Sverjensky, Geochim. Cosmochim. Acta 61, 907 (1997)

[40] V. Ashworth, P.J. Boden, Corros. Sci. 10, 709 (1970) 